\title{
Roles of Brain Angiotensin II in Cognitive Function and Dementia
}

\author{
Masaki Mogi, Jun Iwanami, and Masatsugu Horiuchi \\ Department of Molecular Cardiovascular Biology and Pharmacology, Ehime University Graduate School of Medicine, \\ Shitsukawa, Ehime, Tohon 791-0295, Japan \\ Correspondence should be addressed to Masatsugu Horiuchi, horiuchi@m.ehime-u.ac.jp
}

Received 14 September 2012; Revised 14 November 2012; Accepted 20 November 2012

Academic Editor: Marc de Gasparo

Copyright () 2012 Masaki Mogi et al. This is an open access article distributed under the Creative Commons Attribution License, which permits unrestricted use, distribution, and reproduction in any medium, provided the original work is properly cited.

\begin{abstract}
The brain renin-angiotensin system (RAS) has been highlighted as having a pathological role in stroke, dementia, and neurodegenerative disease. Particularly, in dementia, epidemiological studies indicate a preventive effect of RAS blockade on cognitive impairment in Alzheimer disease (AD). Moreover, basic experiments suggest a role of brain angiotensin II in neural injury, neuroinflammation, and cognitive function and that RAS blockade attenuates cognitive impairment in rodent dementia models of AD. Therefore, RAS regulation is expected to have therapeutic potential for AD. Here, we discuss the role of angiotensin II in cognitive impairment and $\mathrm{AD}$. Angiotensin II binds to the type 2 receptor $\left(\mathrm{AT}_{2}\right)$ and works mainly by binding with the type 1 receptor $\left(\mathrm{AT}_{1}\right) . \mathrm{AT}_{2}$ receptor signaling plays a role in protection against multiple-organ damage. A direct $\mathrm{AT}_{2}$ receptor agonist is now available and is expected to reduce inflammation and oxidative stress and enhance cell differentiation. We and other groups reported that $\mathrm{AT}_{2}$ receptor activation enhances neuronal differentiation and neurite outgrowth in the brain. Here, we also review the effect of the $\mathrm{AT}_{2}$ receptor on cognitive function. RAS modulation may be a new therapeutic option for dementia including $\mathrm{AD}$ in the future.
\end{abstract}

\section{Introduction}

The renin-angiotensin system (RAS) in the brain is well known to be involved in systemic blood pressure control, including the regulation of cerebral blood flow [1]. Angiotensin II, a major player in RAS mainly via the angiotensin type $1\left(\mathrm{AT}_{1}\right)$ receptor, plays an important role in the pathophysiology of tissue dysfunction [2, 3]; therefore, RAS blockade by $\mathrm{AT}_{1}$ receptor blockers (ARBs) and angiotensin converting enzyme inhibitors (ACEIs), which are widely used as antihypertensive drugs, is expected to prevent multiple-organ damage. Cognitive impairment and dementia are common serious health problems that impair quality of life in the elderly. Previous reports indicate the possibility that treatment with antihypertensive agents prevents the impairment of quality of life including cognitive performance $[4,5]$. Possible beneficial effects of RAS blockade on cognitive function are also being highlighted in the clinical field $[6,7]$. An epidemiological study by $\mathrm{Li}$ et al. recently showed that male subjects treated with ARBs exhibited a significant reduction in the incidence and progression of Alzheimer disease $(\mathrm{AD})$ and dementia compared with those treated with ACEIs and other cardiovascular drugs [8]. Moreover, Davies et al. also reported that patients diagnosed with dementia had fewer prescriptions for ARBs and ACEIs. Interestingly, the inverse associations with $\mathrm{AD}$ were stronger for ARBs compared with ACEIs [9]. In contrast, Ohrui et al. demonstrated that long-term use of ACEIs may have a protective role against the development of $\mathrm{AD}$, probably through their direct effects on RAS in the brain [10]. In a subanalysis of the Study on Cognition and Prognosis in the Elderly (SCOPE) trial, hypertensives treated with an ARB, candesartan, showed less decline of specific areas of cognitive function such as attention and episodic memory [11]. However, almost all large clinical intervention trials have shown no significant difference in the incidence of dementia between treatment with ARBs or ACEIs and the placebo group. The Ongoing telmisartan alone and in combination with ramipril global endpoint trial (ONTARGET) and the parallel telmisartan randomized assessment study in ACE intolerant subjects with cardiovascular disease (TRANSCEND) trial showed no clear effects on cognitive 


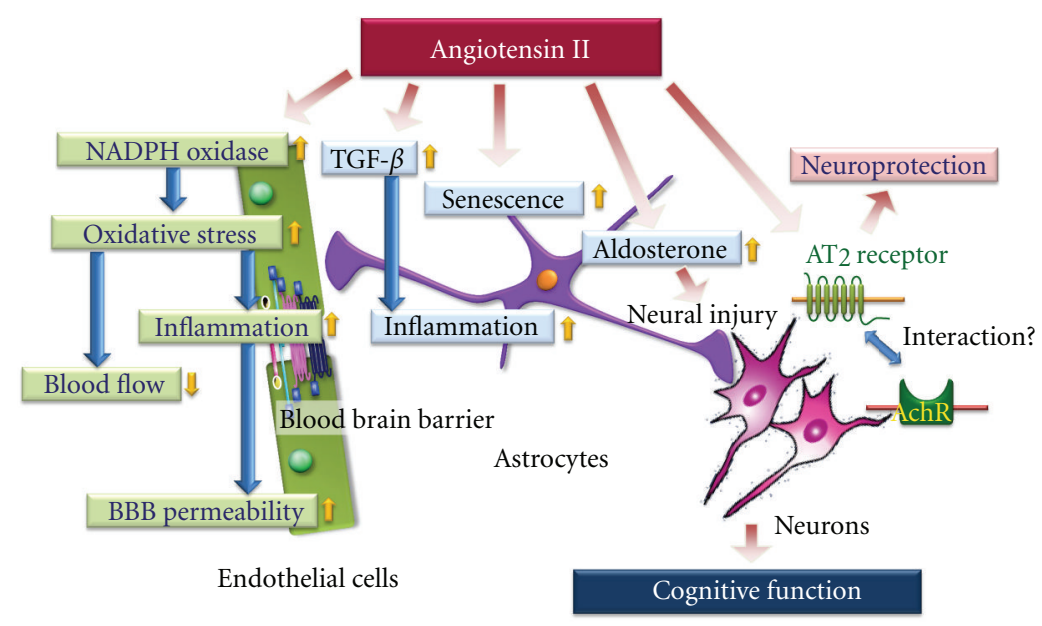

FIgURE 1: Possible effect of angiotensin II on neurovascular unit. $\mathrm{AT}_{2}$ : angiotensin II type 2 receptor, AchR: acetylcholine receptor, BBB: blood brain barrier, and TGF- $\beta$ : transforming growth factor $\beta$.

outcomes [12]. The reason why RAS blockade failed to prevent dementia may be the short-term observation for the long-term preclinical disease stage of dementia; however, the detailed explanation is not clear. Another reason is the selection of hypertensive patients, who have high cardiovascular disease morbidity, in these trials. A large number of these patients are likely to go on to develop dementia, most likely with strong vascular underpinning. In these trials, vascular dementia and $\mathrm{AD}$ are not well distinguished because most studies focused on dementia as subanalysis. As described in the review by Kehoe and Passmore, RAS has multifunctional involvement not only in vascular dementia but also in $\mathrm{AD}$ [13]. Therefore, in such specific groups with cardiovascular risk, the distinction of dementia subtype is very important in comparing the incidence of dementia.

The effect of angiotensin II on cognition has been examined in basic studies. Although the blood-brain barrier is impermeable for all RAS components, the local brain RAS has possible physiological and pharmacological functions in the neuronal system [14]. Gard reviewed the contradictory role of angiotensin II in memory and learning in animal studies [15]. Angiotensin II enhances memory and learning in rodents $[16,17]$, but other studies suggest that angiotensin II decreases cognition [18]. To assess the paradoxical effect of angiotensin II on cognitive function, we therefore performed cognitive tests in mice with continuous activation of angiotensin II, using transgenic mice carrying both the human renin and angiotensinogen genes (hRN/hANG-Tg) [19]. Interestingly, the avoidance rate in hRN/hANG-Tg mice did not increase from 14 weeks of age; however, that from 8 to 13 weeks of age tended to be higher than that in wild-type mice. These findings suggest that the acute or subacute effect of angiotensin II may enhance cognitive function, but chronic treatment with angiotensin II may exhaust neural function and result in cognitive impairment. Angiotensin II induces cerebrovascular remodeling, promotes vascular inflammation and oxidative stress, and results in impairment of regulation of cerebral blood flow (CBF)
$[20,21]$. Moreover, endothelial function in cerebral vessels was impaired in a genetic model of angiotensin-II-dependent hypertension [22, 23]. On the other hand, Lanz et al. showed that angiotensin II induced sustained central nervous system (CNS) inflammation via transforming growth factor(TGF-) $\beta$ in an experimental autoimmune encephalomyelitis (EAE) mouse model [24]. Furthermore, angiotensin II induced astrocyte senescence, which is involved in ageassociated neurodegenerative disease via superoxide production [25]. In contrast, a centrally active ACE inhibitor, perindopril, was reported to prevent cognitive impairment in chronic central hypoperfusion rats [26] and Alzheimer disease model mice [27]. These reports indicate that continuous angiotensin II stimulation impairs cognitive function via stimulation of the $\mathrm{AT}_{1}$ receptor with "environmental degradation of neurons" such as a decrease in CBF and an increase in oxidative stress, CNS inflammation, and cellular senescence in the brain. Such multiple stimuli by angiotensin II induce cognitive impairment following neuronal degeneration.

\section{Effects of Angiotensin II on Amyloid $\beta$ Metabolism and Cholinergic System}

There are two major proposed pathomechanisms of $\mathrm{AD}$; the amyloid cascade hypothesis and the cholinergic hypothesis. Amyloid $\beta(\mathrm{A} \beta)$ is a $39-42$ amino acid peptide, produced by cleavage of amyloid precursor protein (APP) [28]. A $\beta$ (1-42) causes the neurodegenerative abnormalities that lead to clinical AD [29]. Although the effect of angiotensin converting enzyme on $A \beta$ metabolism is one of the hot topics in the relation between RAS and $\mathrm{AD}$ [30], it seems that angiotensin II does not directly affect $A \beta$ secretion or secretase activity via activation of the $\mathrm{AT}_{1}$ receptor [31]. On the other hand, blockade of RAS may affect A $\beta$ metabolism. For example, an ARB, valsartan, was able to attenuate oligomerization of amyloid $\beta$ peptides into high molecular weight oligomeric peptides [32]. Moreover, 


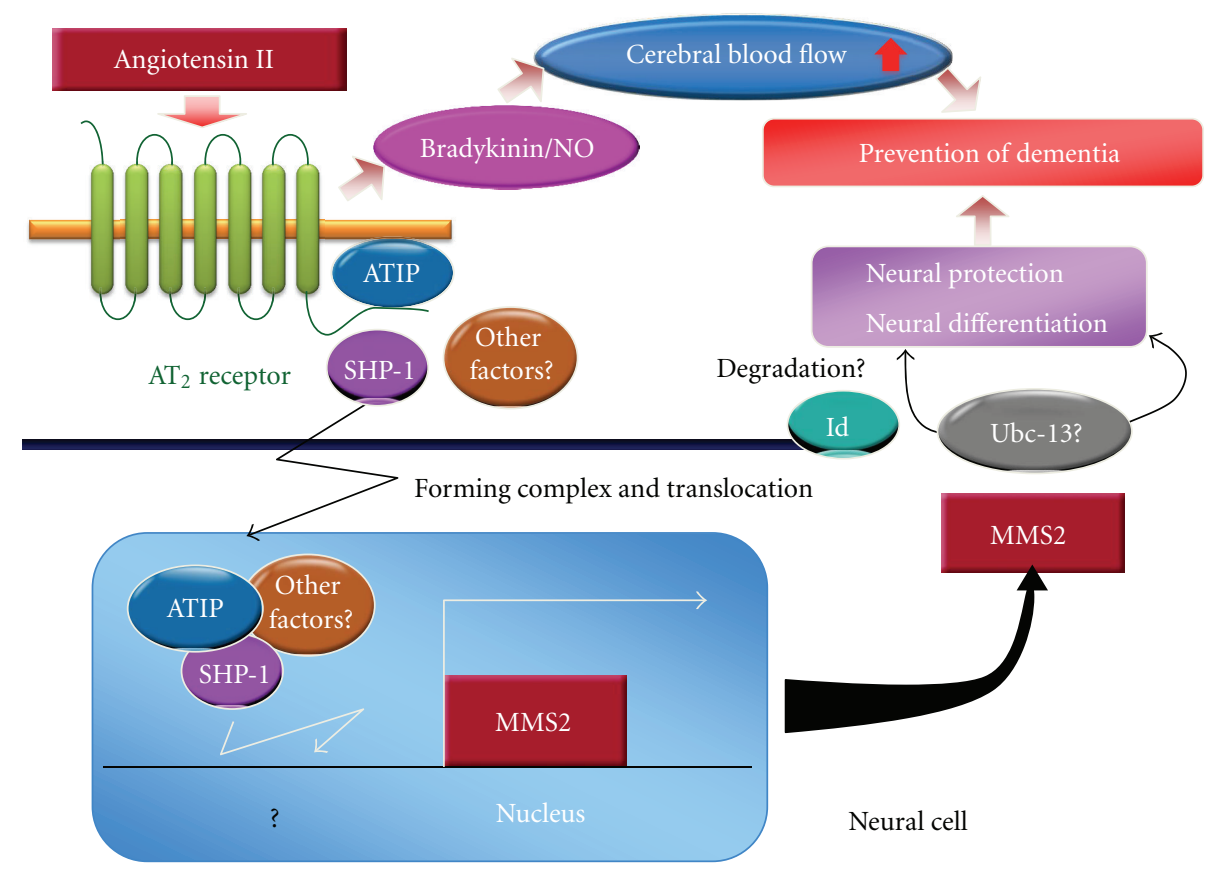

FIGURE 2: Effect of angiotensin II type 2 receptor signaling on cognitive function. $\mathrm{AT}_{2}$ : angiotensin II type 2 receptor, ATIP: AT 2 receptorinteracting protein, Id1: inhibitor of DNA binding protein 1, MMS2: methyl methanesulfonate-sensitive 2, NO: nitric oxide, SHP-1: Src homology 2 domain-containing protein-tyrosine phosphatase 1, and Ubc-13: ubiquitin conjugating enzyme 13.

treatment with valsartan also disrupted the development of amyloid $\beta$-mediated cognitive impairment in $\operatorname{Tg} 2576$ mice, a model of Alzheimer disease; however, it is reported that this beneficial effect is not observed with treatment with other ARBs. We previously reported that $\mathrm{A} \beta$ (1-40) concentration in the brain of ddY mice that underwent intracerebroventricular injection of $\mathrm{A} \beta(1-40)$ was significantly decreased by treatment with an ARB, telmisartan [33]. Moreover, Danielyan et al. reported that intranasal administration of losartan exerts direct neuroprotective effects via its $\mathrm{A} \beta$-reducing and anti-inflammatory effects in the central nervous system [34]. These results indicate that treatment with ARBs may have a beneficial effect on $\mathrm{A} \beta$-induced brain injury through unknown mechanisms on A $\beta$ metabolism by angiotensin II inhibition. On the other hand, brain-penetrating ACEIs such as perindopril prevent cognitive impairment in mice with intracerebroventricular A $\beta$ (1-40) injection via attenuation of oxidative stress and hippocampal astrocyte activation [35]. ACE activity is increased in the hippocampus of these $\mathrm{AD}$ mice and suppressed by perindopril treatment. Although there is concern that ACEIs may enhance brain A $\beta(1-42)$ deposition from basic research [36] because ACE converts $A \beta(1-42)$, which plays a causative role in the development of Alzheimer disease, to A $\beta$ (1-40) [37], recent pilot clinical trials showed that ramipril inhibits cerebrospinal fluid (CSF) ACE activity, but did not influence CSF A $\beta$ (1-42) and cognition [38]. The effects of other RAS components involving angiotensin-IIgenerating enzymes on cognition have also been discussed. $\mathrm{A} \beta$ clearance is induced by many kinds of degrading enzyme such as neprilysin (NEP), insulin-degrading enzyme, and endothelin-converting enzyme. Angiotensin II is also generated by degradation of angiotensinogen and angiotensin I by tonins, cathepsins, and chymases as well as ACE. Gene polymorphism in cathepsin G, one of the angiotensin generating enzymes, showed no significant association with $\mathrm{AD}$ [39]. In our knowledge, no report has examined the relation between tonin, chymase, and dementia; however, inhibition of angiotensin generating enzymes may also inhibit $A \beta$ degradation. Therefore, it is difficult to assess the effect on $\mathrm{A} \beta$ metabolism of drugs that inhibit angiotensin II based on degrading angiotensinogen. Further investigation is necessary to understand the relation among angiotensin II, ACE, other degrading enzymes, and $\mathrm{A} \beta$ metabolism.

In the cholinergic hypothesis, $\mathrm{AD}$ is also characterized by a loss of neurons, especially those expressing nicotinic acetylcholine receptors (nAChR) $[40,41]$. To improve the cognitive deficit in $\mathrm{AD}$, one promising drug target currently under investigation is the neuronal nicotinic alpha7 acetylcholine receptor $(\alpha 7 \mathrm{nAChR})[42,43]$. Although there are few reports about the correlation between $\alpha 7 \mathrm{nAChR}$ and angiotensin II, Marrero's group has demonstrated that angiotensin II blocks nicotine-mediated neuroprotection against $\mathrm{A} \beta$ (142) via activation of the tyrosine phosphatase, SHP-1 [44]. They also showed that angiotensin II inhibits $\alpha 7 \mathrm{nAChR}$ induced activation of the JAK2-PI-3 K cascade in PC12 cells through $\mathrm{AT}_{2}$ receptor-induced SHP-1 activation [45]. However, $\mathrm{AT}_{2}$ receptor-induced SHP-1 activation also induces cerebellar development and neural differentiation $[46,47]$. Moreover, $\mathrm{A} \beta$ triggered $\mathrm{AT}_{2}$ receptor oligomerization in 


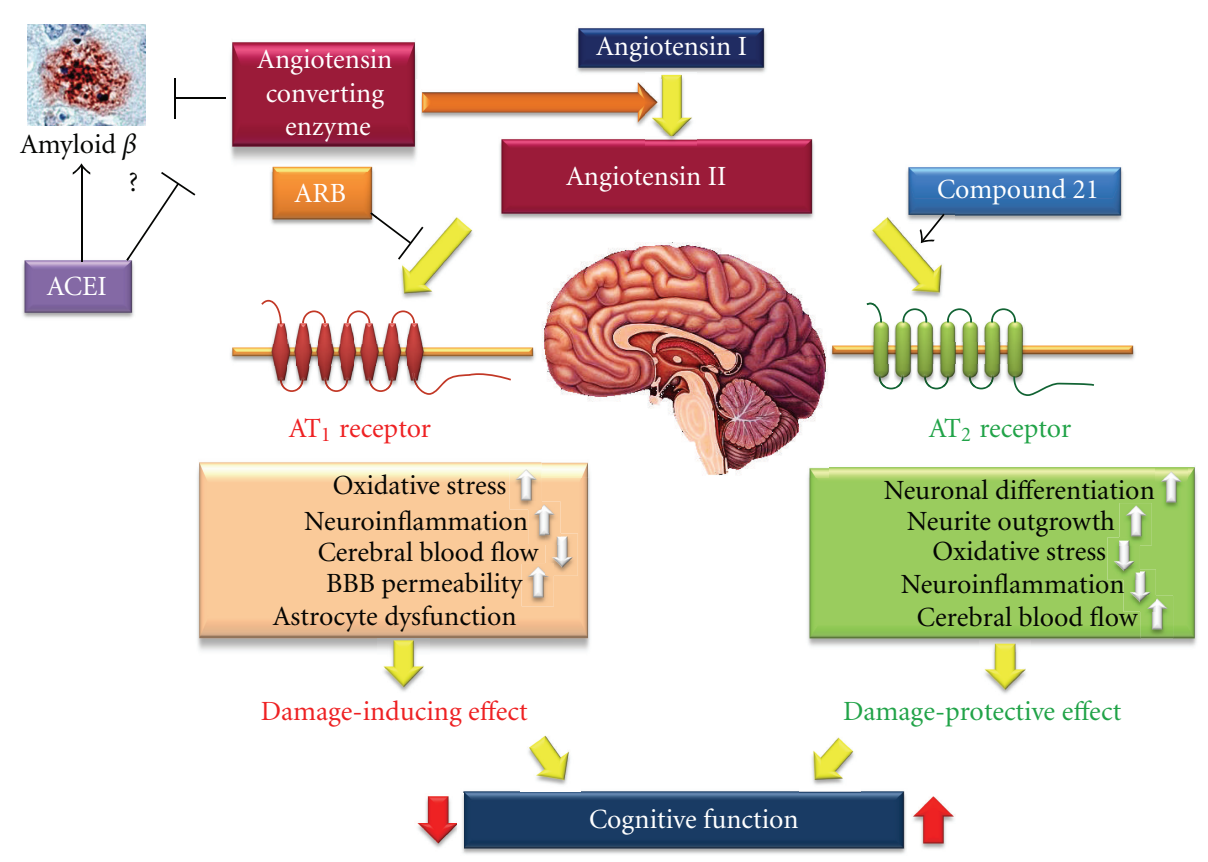

FIGURE 3: Effect of angiotensin II on cognitive function. ACE: angiotensin converting enzyme inhibitor, $\mathrm{AT}_{1}$ : angiotensin II type 1 receptor, $\mathrm{AT}_{2}$ : angiotensin II type 2 receptor, and ARB: angiotensin II type 1 receptor blocker.

the hippocampus [48] and impaired coupling of the muscarinic acetylcholine receptor $(\mathrm{mAChR})$ to heterotrimeric GTP-binding proteins $(\mathrm{G} \alpha \mathrm{q} / 11)$ [49]. Therefore, the $\mathrm{AT}_{2}$ receptor may interact with the cholinergic system; however, the actual effect of angiotensin II mediated by AChRs is still an enigma (Figure 1).

\section{Effects of Angiotensin II on Neurovascular Unit}

Nonneuronal cells such as vascular cells and glia (astrocytes, microglia and oligodendroglia) comprise the "neurovascular unit" and could play important roles in disease pathogenesis [50]. Especially, CBF functions in concert as a part of the neurovascular unit to maintain homeostasis of the cerebral microenvironment [51]. Iadecola and colleagues demonstrated that angiotensin II increases the production of reactive oxygen species (ROS) in cerebral microvessels via gp91phox (nox-2), a subunit of NADPH oxidase $[20,51]$. Moreover, recently they also demonstrated that slow infusion of the pressor angiotensin II induces attenuation of the increase in CBF induced by neural activity (whisker stimulation) and by endothelium-dependent vasodilators, without elevation of mean arterial pressure (MAP) [52]. Such an effect of angiotensin II reduces blood supply and contributes to increased susceptibility to dementia. Interestingly, this angiotensin-induced cerebrovascular dysregulation was attenuated in female compared with male mice [53]. This sexual dimorphism of the cerebral blood-vessel response to angiotensin II may be implicated in the sex difference in cognitive impairment reported in epidemiological studies [54]. On the other hand, Takeda et al. demonstrated that the
ARB olmesartan ameliorates amyloid $\beta$-induced impairment of functional hyperemia evoked by whisker stimulation via a decrease in oxidative stress in brain microvessels [55]. Recently, Zhang et al. reported that angiotensin II increases cerebral microvasculature inflammation via induction of oxidative stress and leads to immune-endothelial interaction, resulting in enhancement of BBB permeability [56]. Therefore, angiotensin-II-induced oxidative stress may have a key role in dysfunction of the neurovascular unit (Figure 1).

On the other hand, several reports indicate the effect of angiotensin II on astrocytes to be neuroinflammation, neuronal damage and astrocyte senescence. For example, Lanz et al. clearly demonstrated that angiotensin II acts as a paracrine mediator, sustaining inflammation in the CNS via TGF- $\beta$ upregulation in astrocytes [24]. We also reported that aldosterone secretion induced by angiotensin II in astrocytes enhances neuronal damage due to angiotensin II [57]. Moreover, Liu et al. showed that angiotensin II induces astrocyte senescence via superoxide production [25]. These findings of astrocyte dysfunction induced by angiotensin II also explain the crucial role of angiotensin II in dysfunction of the neurovascular unit (Figure 1).

\section{Effect of $\mathbf{A T}_{2}$ Receptors on Cognition and Dementia}

The major actions of angiotensin II are mediated by the $\mathrm{AT}_{1}$ receptor, whereas the role of a second receptor subtype known as the angiotensin II type $2\left(\mathrm{AT}_{2}\right)$ receptor is suggested to be protecting of the brain [58]. In the brain, $\mathrm{AT}_{2}$ receptors are expressed not only in the vascular wall but also in areas related to learning and control of motor 
activity $[59,60]$. Mice with deletion of the $\mathrm{AT}_{2}$ receptor were reported to exhibit worse cognitive function compared with wild-type mice [60]. Reinecke et al. demonstrated the possibility that stimulation of the $\mathrm{AT}_{2}$ receptor may promote cell differentiation and regeneration in neuronal tissue [61] and that $\mathrm{AT}_{2}$ receptor stimulation supported neuronal survival and neurite outgrowth in response to ischemiainduced neuronal injury [62]. We also demonstrated that $\mathrm{AT}_{2}$ receptor signaling enhanced neural differentiation and the repair of damaged DNA through induction of a neural differentiating factor, methyl methanesulfonate-sensitive 2 (MMS2), which is one of the ubiquitin conjugating enzyme variants [47]. Moreover, Gallo-Payet et al. reported that angiotensin II induces neural differentiation and neurite outgrowth via mitogen-activated protein kinase [63] or nitric oxide [64] through $\mathrm{AT}_{2}$ receptor activation, and is involved in cerebellar development [65]. Therefore, direct $\mathrm{AT}_{2}$ receptor stimulation is expected to have a beneficial effect on cognitive function. We examined the possibility that direct stimulation of the $\mathrm{AT}_{2}$ receptor by a newly generated direct $\mathrm{AT}_{2}$ receptor agonist, Compound 21 (C21), would enhance cognitive function [66]. Daily intraperitoneal injection of C21 for 2 weeks significantly enhanced spatial learning evaluated by the Morris water maze test in C57BL6 mice, but this effect was not observed in $\mathrm{AT}_{2}$ receptor-deficient mice. $\mathrm{C} 21$ treatment increased cerebral blood flow assessed by laser speckle flowmetry and hippocampal field-excitatory postsynaptic potential. Moreover, treatment with C21 prevented cognitive decline in an Alzheimer disease mouse model with intracerebroventricular injection of amyloid $\beta(1-40)$. $\mathrm{AT}_{2}$ receptor activation is reported to stimulate the release of $\mathrm{NO} / \mathrm{cGMP}$ and may mediate vascular relaxation and blood flow indirectly through modulation of bradykinin release [67]. In our model, C21-induced cognitive enhancement was attenuated by coadministration of icatibant, a bradykinin $\mathrm{B}_{2}$ receptor antagonist. Therefore, direct activation of the $\mathrm{AT}_{2}$ receptor improves spatial learning via an increase in microcirculation, partly through modulation of bradykinin. The preventive effect of $\mathrm{AT}_{2}$ receptor signaling on dementia is summarized in Figure 2. Clinical use of C21 is expected to be a new therapeutic option in patients with dementia.

\section{Conclusion}

Continuous stimulation with angiotensin II may damage neurons via multiple cascades through $\mathrm{AT}_{1}$ receptor stimulation. On the other hand, stimulation of the $\mathrm{AT}_{2}$ receptor is expected to prevent neural damage and cognitive impairment (Figure 3). However, it is difficult to perform clinical intervention studies to confirm the results of animal studies because of the long-term progression of cognitive impairment. Moreover, in clinical practice, it is not possible to exclude the antihypertensive effect of RAS blockade on cognition in patients with hypertension. However, RAS modulation may be a new therapeutic option for dementia including $\mathrm{AD}$ in the future. Therefore, the hypothesis that RAS regulation affects future cognitive function should be confirmed with carefully designed clinical studies.

\section{Abbreviations}

$\begin{array}{ll}\text { AD: } & \text { Alzheimer disease } \\ \text { ARB: } & \begin{array}{l}\text { Angiotensin II type 1 }\left(\mathrm{AT}_{1}\right) \text { receptor } \\ \text { blocker }\end{array} \\ \mathrm{AT}_{1} \text { receptor: } & \text { Angiotensin II type 1 receptor } \\ \mathrm{AT}_{2} \text { receptor: } & \text { Angiotensin II type 2 receptor } \\ \mathrm{ACE}: & \text { Angiotensin converting enzyme } \\ \mathrm{CBF}: & \text { Cerebral surface blood flow } \\ \text { hRN/hANG-Tg: } & \begin{array}{l}\text { Human renin and angiotensinogen } \\ \text { genes }\end{array} \\ \text { RAS: } & \text { Renin-angiotensin system } \\ \text { si: } & \text { Small interfering } \\ \text { MMS2: } & \text { Methyl methanesulfonate-sensitive } 2 .\end{array}$

\section{Conflict of Interests}

The authors declare no conflict of interests.

\section{Acknowledgment}

This work was supported by grants from the Ministry of Education, Science, Sports, and Culture of Japan to M. Mogi, J. Iwanami, and M. Horiuchi.

\section{References}

[1] M. de Gasparo, K. J. Catt, T. Inagami, J. W. Wright, and T. Unger, "International union of pharmacology. XXIII. The angiotensin II receptors," Pharmacological Reviews, vol. 52, no. 3, pp. 415-472, 2000.

[2] R. E. Schmieder, K. F. Hilgers, M. P. Schlaich, and B. M. Schmidt, "Renin-angiotensin system and cardiovascular risk," The Lancet, vol. 369, no. 9568, pp. 1208-1219, 2007.

[3] J. Iwanami, M. Mogi, M. Iwai, and M. Horiuchi, "Inhibition of the renin-angiotensin system and target organ protection," Hypertension Research, vol. 32, no. 4, pp. 229-237, 2009.

[4] R. Fogari and A. Zoppi, "Effect of antihypertensive agents on quality of life in the elderly," Drugs and Aging, vol. 21, no. 6, pp. 377-393, 2004.

[5] A. Fletcher, "Quality of life in the management of hypertension," Clinical and Experimental Hypertension, vol. 21, no. 5-6, pp. 961-972, 1999.

[6] J. W. Wright and J. W. Harding, "The brain RAS and Alzheimer's disease," Experimental Neurology, vol. 223, no. 2, pp. 326-333, 2010.

[7] M. Mogi and M. Horiuchi, "Effects of angiotensin II receptor blockers on dementia," Hypertension Research, vol. 32, no. 9, pp. 738-740, 2009.

[8] N. C. Li, A. Lee, R. A. Whitmer et al., "Use of angiotensin receptor blockers and risk of dementia in a predominantly male population: prospective cohort analysis," British Medical Journal, vol. 340, p. b5465, 2010.

[9] N. M. Davies, P. G. Kehoe, Y. Ben-Shlomo, and R. M. Martin, "Associations of anti-hypertensive treatments with Alzheimer's disease, vascular dementia, and other dementias," Journal of Alzheimer's Disease, vol. 26, no. 4, pp. 699-708, 2011.

[10] T. Ohrui, T. Matsui, M. Yamaya et al., "Angiotensin-converting enzyme inhibitors and incidence of Alzheimer's disease in Japan [7]," Journal of the American Geriatrics Society, vol. 52, no. 4, pp. 649-650, 2004. 
[11] B. K. Saxby, F. Harrington, K. A. Wesnes, I. G. McKeith, and G. A. Ford, "Candesartan and cognitive decline in older patients with hypertension: a substudy of the SCOPE trial," Neurology, vol. 70, no. 19, pp. 1858-1866, 2008.

[12] C. Anderson, K. Teo, P. Gao et al., "Renin-angiotensin system blockade and cognitive function in patients at high risk of cardiovascular disease: analysis of data from the ONTARGET and TRANSCEND studies," The Lancet Neurology, vol. 10, no. 1, pp. 43-53, 2011.

[13] P. G. Kehoe and P. A. Passmore, "The renin-angiotensin system and antihypertensive drugs in Alzheimer's disease: current standing of the angiotensin hypothesis?" Journal of Alzheimer's Disease, vol. 30, supplement 2, pp. S251-S268, 2012.

[14] J. W. Wright and J. W. Harding, "Brain renin-angiotensin-A new look at an old system," Progress in Neurobiology, vol. 95, no. 1, pp. 49-67, 2011.

[15] P. R. Gard, "The role of angiotensin II in cognition and behaviour," European Journal of Pharmacology, vol. 438, no. 12, pp. 1-14, 2002.

[16] V. Georgiev and D. Yonkov, "Participation of angiotensin II in learning and memory. I. Interaction of angiotensin II with saralasin," Methods and Findings in Experimental and Clinical Pharmacology, vol. 7, no. 8, pp. 415-418, 1985.

[17] A. Kułakowska, W. Karwowska, K. Wiśniewski, and J. J. Braszko, "Losartan influences behavioural effects of angiotensin II in rats," Pharmacological Research, vol. 34, no. 3-4, pp. 109-115, 1996.

[18] V. Raghavendra, K. Chopra, and S. K. Kulkarni, "Involvement of cholinergic system in losartan-induced facilitation of spatial and short-term working memory," Neuropeptides, vol. 32, no. 5, pp. 417-421, 1998.

[19] S. Inaba, M. Iwai, M. Furuno et al., "Continuous activation of renin-angiotensin system impairs cognitive function in renin/angiotensinogen transgenic mice," Hypertension, vol. 53, no. 2, pp. 356-362, 2009.

[20] K. Kazama, J. Anrather, P. Zhou et al., "Angiotensin II impairs neurovascular coupling in neocortex through NADPH oxidase-derived radicals," Circulation Research, vol. 95, no. 10, pp. 1019-1026, 2004.

[21] Y. Wei, A. T. Whaley-Connell, K. Chen et al., "NADPH oxidase contributes to vascular inflammation, insulin resistance, and remodeling in the transgenic (mRen2) rat," Hypertension, vol. 50, no. 2, pp. 384-391, 2007.

[22] S. P. Didion, C. D. Sigmund, and F. M. Faraci, "Impaired endothelial function in transgenic mice expressing both human renin and human angiotensinogen," Stroke, vol. 31, no. 3, pp. 760-765, 2000.

[23] F. M. Faraci, K. G. Lamping, M. L. Modrick, M. J. Ryan, C. D. Sigmund, and S. P. Didion, "Cerebral vascular effects of angiotensin II: new insights from genetic models," Journal of Cerebral Blood Flow and Metabolism, vol. 26, no. 4, pp. 449455, 2006.

[24] T. V. Lanz, Z. Ding, P. P. Ho et al., "Angiotensin II sustains brain inflammation in mice via TGF- $\beta$," Journal of Clinical Investigation, vol. 120, no. 8, pp. 2782-2794, 2010.

[25] G. Liu, N. Hosomi, H. Hitomi et al., "Angiotensin II induces human astrocyte senescence through reactive oxygen species production," Hypertension Research, vol. 34, no. 4, pp. 479483, 2011.

[26] K. Yamada, T. Horita, M. Takayama et al., "Effect of a centrally active angiotensin converting enzyme inhibitor, perindopril, on cognitive performance in chronic cerebral hypo-perfusion rats," Brain Research, vol. 1421, no. 1, pp. 10-120, 2011.
[27] K. Yamada, S. Uchida, S. Takahashi et al., "Effect of a centrally active angiotensin-converting enzyme inhibitor, perindopril, on cognitive performance in a mouse model of Alzheimer's disease," Brain Research C, vol. 1352, pp. 176-186, 2010.

[28] W. E. Van Nostrand, J. Davis-Salinas, and S. M. SaporitoIrwin, "Amyloid $\beta$-protein induces the cerebrovascular cellular pathology of Alzheimer's disease and related disorders," Annals of the New York Academy of Sciences, vol. 777, pp. 297302, 1996.

[29] J. Hardy and D. J. Selkoe, "The amyloid hypothesis of Alzheimer's disease: progress and problems on the road to therapeutics," Science, vol. 297, no. 5580, pp. 353-356, 2002.

[30] K. Zou and M. Michikawa, "Angiotensin-converting enzyme as a potential target for treatment of Alzheimer's disease: inhibition or activation?" Reviews in the Neurosciences, vol. 19, no. 4-5, pp. 203-212, 2008.

[31] B. R. Wang, J. Q. Shi, Y. D. Zhang, D. L. Zhu, and J. P. Shi, "Angiotensin II does not directly affect $\mathrm{A} \beta$ secretion or $\beta$ $/ \gamma$-secretase activity via activation of angiotensin II type 1 receptor," Neuroscience Letters, vol. 500, no. 2, pp. 103-107, 2011.

[32] J. Wang, L. Ho, L. Chen et al., "Valsartan lowers brain $\beta$-amyloid protein levels and improves spatial learning in a mouse model of Alzheimer disease," Journal of Clinical Investigation, vol. 117, no. 11, pp. 3393-3402, 2007.

[33] K. Tsukuda, M. Mogi, J. Iwanami et al., "Cognitive deficit in amyloid- $\beta$-injected mice was improved by pretreatment with a low dose of telmisartan partly because of peroxisome proliferator-activated receptor- $\gamma$ activation," Hypertension, vol. 54, no. 4, pp. 782-787, 2009.

[34] L. Danielyan, R. Klein, L. R. Hanson et al., "Protective effects of intranasal losartan in the APP/PS1 transgenic mouse model of Alzheimer disease," Rejuvenation Research, vol. 13, no. 2-3, pp. 195-201, 2010.

[35] Y. F. Dong, K. Kataoka, Y. Tokutomi et al., "Perindopril, a centrally active angiotensin-converting enzyme inhibitor, prevents cognitive impairment in mouse models of Alzheimer's disease," FASEB Journal, vol. 25, no. 9, pp. 2911-2920, 2011.

[36] M. L. Hemming and D. J. Selkoe, "Amyloid $\beta$-protein is degraded by cellular angiotensin-converting enzyme (ACE) and elevated by an ACE inhibitor," Journal of Biological Chemistry, vol. 280, no. 45, pp. 37644-37650, 2005.

[37] K. Zou, T. Maeda, A. Watanabe et al., "A $\beta 42-$ to-A $\beta 40-$ and angiotensin-converting activities in different domains of angiotensin-converting enzyme," Journal of Biological Chemistry, vol. 284, no. 46, pp. 31914-31920, 2009.

[38] W. Wharton, J. H. Stein, C. Korcarz et al., "The effects of ramipril in individuals at risk for Alzheimer's disease: results of a pilot clinical trial," Journal of Alzheimer's Disease, vol. 32, no. 1, pp. 147-156, 2012.

[39] T. J. Bhojak, S. T. DeKosky, M. Ganguli, and M. I. Kamboh, "Genetic polymorphism in the cathepsin G gene and the risk of Alzheimer's disease," Neuroscience Letters, vol. 309, no. 2, pp. 138-140, 2001.

[40] A. Kadir, O. Almkvist, A. Wall, B. Långström, and A. Nordberg, "PET imaging of cortical 11C-nicotine binding correlates with the cognitive function of attention in Alzheimer's disease," Psychopharmacology, vol. 188, no. 4, pp. 509-520, 2006.

[41] S. D. Buckingham, A. K. Jones, L. A. Brown, and D. B. Sattelle, "Nicotinic acetylcholine receptor signalling: roles in alzheimer's disease and amyloid neuroprotection," Pharmacological Reviews, vol. 61, no. 1, pp. 39-61, 2009. 
[42] H. Y. Wang, D. H. S. Lee, M. R. D’Andrea, P. A. Peterson, R. P. Shank, and A. B. Reitz, " $\beta$-Amyloid1-42 binds to $\alpha 7$ nicotinic acetylcholine receptor with high affinity. Implications for Alzheimer's disease pathology," Journal of Biological Chemistry, vol. 275, no. 8, pp. 5626-5632, 2000.

[43] H. R. Parri, C. M. Hernandez, and K. T. Dineley, "Research update: alpha7 nicotinic acetylcholine receptor mechanisms in Alzheimer's disease," Biochemical Pharmacology, vol. 82, no. 8, pp. 931-942, 2011.

[44] S. Shaw, M. Bencherif, and M. B. Marrero, "Angiotensin II blocks nicotine-mediated neuroprotection against $\beta$-amyloid (1-42) via activation of the tyrosine phosphatase SHP-1," Journal of Neuroscience, vol. 23, no. 35, pp. 11224-11228, 2003.

[45] M. B. Marrero and M. Bencherif, "Convergence of alpha 7 nicotinic acetylcholine receptor-activated pathways for antiapoptosis and anti-inflammation: central role for JAK2 activation of STAT3 and NF- $\kappa$ B," Brain Research $C$, vol. 1256, pp. $1-7,2009$.

[46] L. R. Seguin, R. S. Villarreal, and G. M. Ciuffo, "AT2 receptors recruit c-Src, SHP-1 and FAK upon activation by ang II in PND15 rat hindbrain," Neurochemistry International, vol. 60, no. 2, pp. 199-207, 2012.

[47] J. M. Li, M. Mogi, K. Tsukuda et al., "Angiotensin II-induced neural differentiation via angiotensin II type 2 (AT2) receptorMMS2 cascade involving interaction between AT 2 receptorinteracting protein and Src homology 2 domain-containing protein-tyrosine phosphatase 1," Molecular Endocrinology, vol. 21, no. 2, pp. 499-511, 2007.

[48] S. AbdAlla, H. Lother, A. El Missiry et al., "Angiotensin II AT2 receptor oligomers mediate G-protein dysfunction in an animal model of Alzheimer disease," Journal of Biological Chemistry, vol. 284, no. 10, pp. 6554-6565, 2009.

[49] P. J. Tienari, B. De Strooper, E. Ikonen et al., "The $\beta$-amyloid domain is essential for axonal sorting of amyloid precursor protein," EMBO Journal, vol. 15, no. 19, pp. 5218-5229, 1996.

[50] C. Iadecola, "The overlap between neurodegenerative and vascular factors in the pathogenesis of dementia," Acta Neuropathologica, vol. 120, no. 3, pp. 287-296, 2010.

[51] H. Girouard, L. Park, J. Anrather, P. Zhou, and C. Iadecola, "Angiotensin II attenuates endothelium-dependent responses in the cerebral microcirculation through nox-2-derived radicals," Arteriosclerosis, Thrombosis, and Vascular Biology, vol. 26, no. 4, pp. 826-832, 2006.

[52] C. Capone, G. Faraco, L. Park, X. Cao, R. L. Davisson, and C. Iadecola, "The cerebrovascular dysfunction induced by slow pressor doses of angiotensin II precedes the development of hypertension," American Journal of Physiology-Heart and Circulatory Physiology, vol. 300, no. 1, pp. H397-H407, 2011.

[53] H. Girouard, A. Lessard, C. Capone, T. A. Milner, and C. Iadecola, "The neurovascular dysfunction induced by angiotensin II in the mouse neocortex is sexually dimorphic," American Journal of Physiology-Heart and Circulatory Physiology, vol. 294, no. 1, pp. H156-H163, 2008.

[54] G. A. Laughlin, L. K. McEvoy, D. von Muhlen et al., "Sex differences in the association of Framingham cardiac risk score with cognitive decline in community-dwelling elders without clinical heart disease," Psychosomatic Medicine, vol. 73, no. 8, pp. 683-689, 2011.

[55] S. Takeda, N. Sato, D. Takeuchi et al., "Angiotensin receptor blocker prevented $\beta$-amyloid-induced cognitive impairment associated with recovery of neurovascular coupling," Hypertension, vol. 54, no. 6, pp. 1345-1352, 2009.
[56] M. Zhang, Y. Mao, S. H. Ramirez, R. F. Tuma, and T. Chabrashvili, "Angiotensin II induced cerebral microvascular inflammation and increased blood-brain barrier permeability via oxidative stress," Neuroscience, vol. 171, no. 3, pp. 852-858, 2010.

[57] L. J. Min, M. Mogi, J. Iwanami et al., "Angiotensin II and aldosterone-induced neuronal damage in neurons through an astrocyte-dependent mechanism," Hypertension Research, vol. 34, no. 6, pp. 773-778, 2011.

[58] M. Horiuchi, M. Mogi, and M. Iwai, "The angiotensin II type 2 receptor in the brain," Journal of the Renin-AngiotensinAldosterone System, vol. 11, no. 1, pp. 1-6, 2010.

[59] M. Iwai, H. W. Liu, R. Chen et al., "Possible inhibition of focal cerebral ischemia by angiotensin II type 2 receptor stimulation," Circulation, vol. 110, no. 7, pp. 843-848, 2004.

[60] M. Mogi, J. M. Li, J. Iwanami et al., "Angiotensin II type2 receptor stimulation prevents neural damage by transcriptional activation of methyl methanesulfonate sensitive 2," Hypertension, vol. 48, no. 1, pp. 141-148, 2006.

[61] K. Reinecke, R. Lucius, A. Reinecke, U. Rickert, T. Herdegen, and T. Unger, "Angiotensin II accelerates functional recovery in the rat sciatic nerve in vivo: role of the AT2 receptor and the transcription factor NF-kappaB," FASEB Journal, vol. 17, no. 14, pp. 2094-2096, 2003.

[62] J. Li, J. Culman, H. Hörtnagl et al., "Angiotensin AT2 receptor protects against cerebral ischemia-induced neuronal injury," FASEB Journal, vol. 19, no. 6, pp. 617-619, 2005.

[63] L. Gendron, L. Laflamme, N. Rivard, C. Asselin, M. D, Payet, and N. Gallo-Payet, "Signals from the AT2 (angiotensin type 2) receptor of angiotensin II inhibit p21(ras) and activate MAPK (mitogen-activated protein kinase) to induce morphological neuronal differentiation in NG108-15 cells," Molecular Endocrinology, vol. 13, no. 9, pp. 1615-1626, 1999.

[64] F. Cote, L. Laflamme, M. D. Payet, and N. Gallo-Payet, "Nitric oxide, a new second messenger involved in the action of angiotensin II on neuronal differentiation of NG108-15 cells," Endocrine Research, vol. 24, no. 3-4, pp. 403-407, 1998.

[65] F. Côté, T. H. Do, L. Laflamme, J. M. Gallo, and N. GalloPayet, "Activation of the AT2 receptor of angiotensin II induces neurite outgrowth and cell migration in microexplant cultures of the cerebellum," Journal of Biological Chemistry, vol. 274, no. 44, pp. 31686-31692, 1999.

[66] F. Jing, M. Mogi, A. Sakata et al., "Direct stimulation of angiotensin II type 2 receptor enhances spatial memory," Journal of Cerebral Blood Flow and Metabolism, vol. 32, no. 2, pp. 248-255, 2011.

[67] O. Jöhren, A. Dendorfer, and P. Dominiak, "Cardiovascular and renal function of angiotensin II type-2 receptors," Cardiovascular Research, vol. 62, no. 3, pp. 460-467, 2004. 


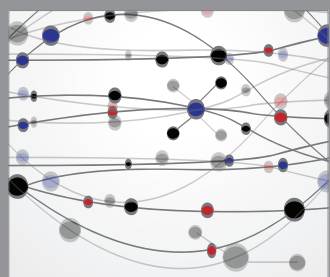

The Scientific World Journal
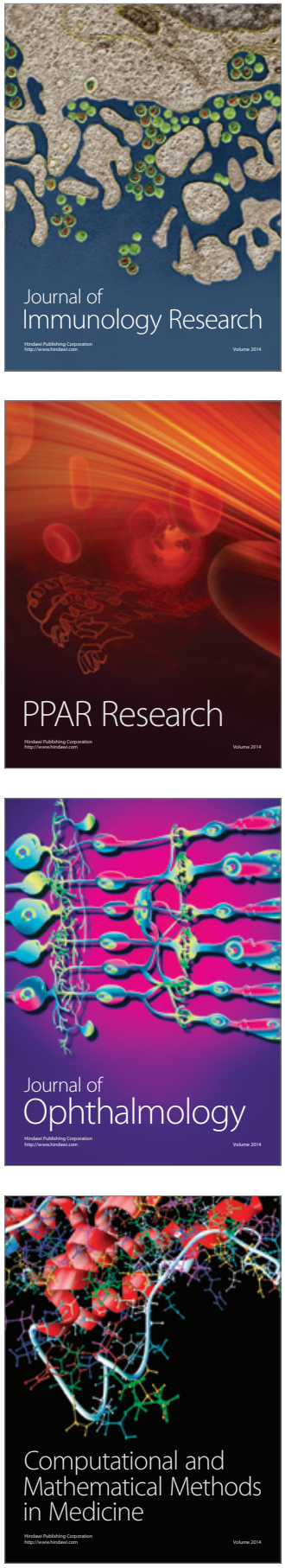

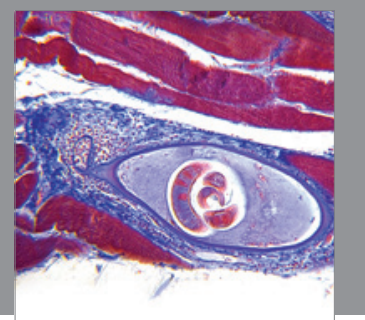

Gastroenterology

Research and Practice
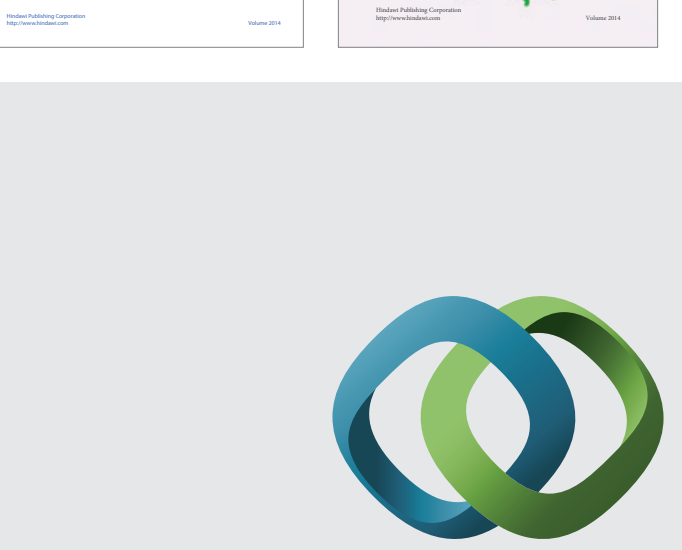

\section{Hindawi}

Submit your manuscripts at

http://www.hindawi.com
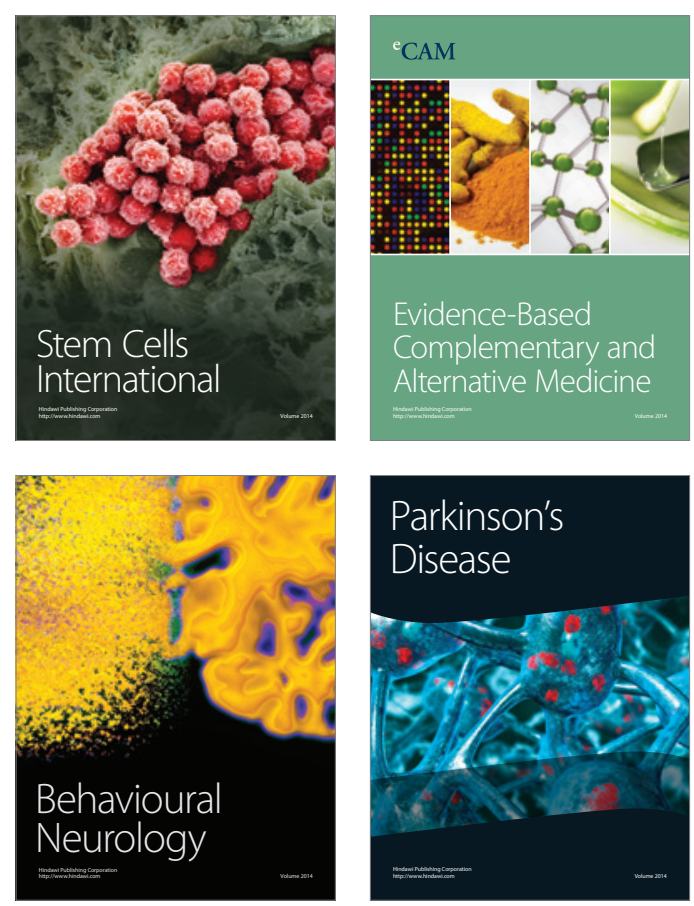

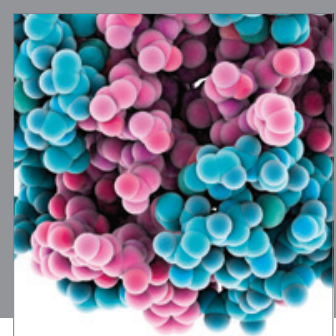

Journal of
Diabetes Research

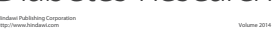

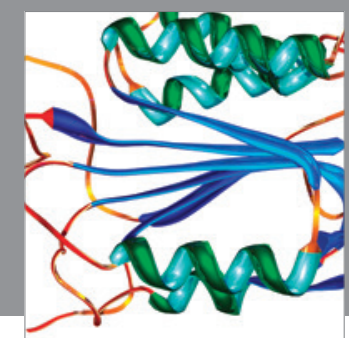

Disease Markers
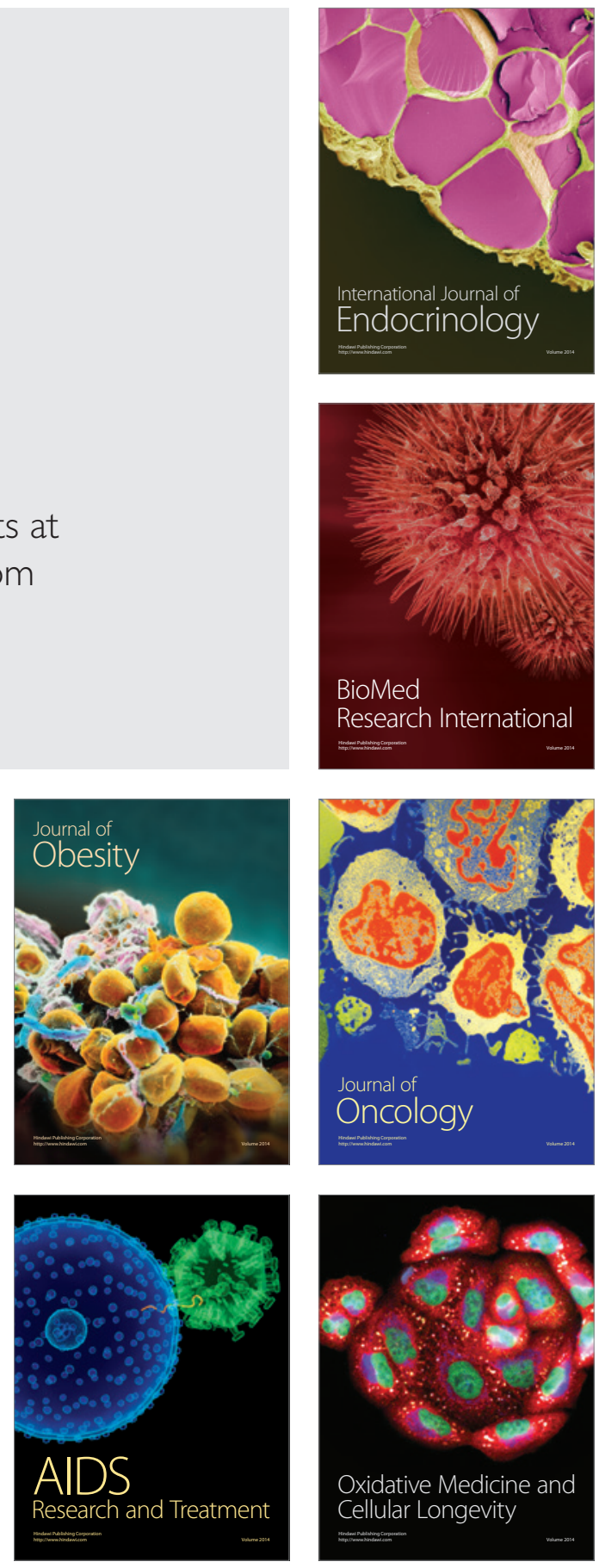